\title{
STUDI PENGARUH PERBANDINGAN REAKTAN LIGNIN NaHSO 3 DAN pH TERHADAP NATRIUM LIGNOSULFONAT (NaLS)
}

\author{
Gustini Syahbirin $^{1}$, Ani Suryani ${ }^{2}$, Tesar Dzikrulloh ${ }^{1}$ \\ ${ }^{1}$ Departemen Kimia FMIPA Institut Pertanian Bogor \\ ${ }^{2}$ Teknologi Industri Pertanian, Institut Pertanian Bogor
}

\begin{abstract}
Lignin was isolated from waste black liquor of soda pulping process. Sulfonation of soda lignin produced Sodium Lignosulfonate (NaLS) which can be used as dispersants, and concrete admixtures. In this research, sulfonation was carried out towards lignin with ratio of lignin$\mathrm{NaHSO}_{3}$ of 1.0:0.4; 1.0:0.5; and 1.0:0.6, and initial $\mathrm{pH}$ of $5.00 ; 6.00 ; 7.00$. Parameters observed were purity, final $\mathrm{pH}$, and yield of $\mathrm{NaLS}$. The upsurge of initial $\mathrm{pH}$ increased the final $\mathrm{pH}$ and $\mathrm{NaLS}$ yield, but decreased its purity. The upsurge of ratio of lignin- $\mathrm{NaHSO}_{3}$ increased $\mathrm{NaLS}$ yield and decreased its purity, but did not affect the final $\mathrm{pH}$ of NaLS. The chosen optimum condition was on $\mathrm{pH}$ of 6.00 and ratio of lignin- $\mathrm{NaHSO}_{3}$ of 1.0:0.6. Characterization of functional group using FTIR, and purity of NaLS using UV-Visible Absorption Spectrophotometer.
\end{abstract}

Keywords: soda lignin, sulfonation of lignin, sodium lignosulfonate

\section{PENDAHULUAN}

Lignosulfonat (LS) adalah lignin yang mengandung gugus sulfonat, sehingga larut dalam air. Penggunaan lignosulfonat sangat beragam, diantaranya sebagai bahan tambahan (admixture) pada semen dan beton, sebagai penstabil tanah dalam industri pengeboran minyak, pendispersi warna pada industri tekstil, emulsifier dalam pembuatan pelumas, bahan perekat untuk papan gipsum, hingga sebagai bahan aditif untuk media kultur ${ }^{[1]}$.

Sifat larut air yang dimiliki lignosulfonat membuatnya banyak digunakan juga sebagai bahan untuk membantu proses pengadukan dalam cement mill, dan membuat konstruksi bangunan menjadi lebih kokoh karena lignosulfonat juga bersifat sebagai bahan pengikat (binding agent) yang sangat baik ${ }^{[2]}$. Lignosulfonat digunakan sebagai admixtures (bahan tambahan kimia) pada campuran semen dengan adanya sifat pendispersi dan aktivitas permukaan yang dimilikinya ${ }^{[3]}$.

Salah satu bahan baku yang dapat digunakan pada proses pembuatan lignosulfonat adalah lignin. Lignin merupakan polimer alami yang terdiri dari gabungan unit-unit fenilpropana.
Lignin adalah salah satu komponen utama di dalam tumbuhan yang terdapat dalam dinding sel tumbuh-tumbuhan. Lignin bersama selulosa menyebabkan kekakuan dan kekokohan batang tumbuh-tumbuhan ${ }^{[4,5]}$.

Limbah industri pulp dan kertas juga dapat dimanfaatkan pada proses pembuatan lignosulfonat. Lignin merupakan komponen utama pada limbah lindi hitam (black liquor) yang dihasilkan oleh limbah pabrik pulp melalui proses kimia pada proses produksinya.

Kandungan lignin pada lindi hitam dapat mencapai 12,0 - 37,5\%. Lindi hitam bila tidak didaur ulang merupakan salah satu sumber pencemaran lingkungan yang potensial, disebabkan oleh adanya beberapa senyawa kimia, seperti metil merkaptan, dan hidrogen sulfida yang bersifat racun. Di samping dapat mengurangi masalah pencemaran yang diakibatkan oleh lindi hitam pabrik pulp, kandungan lignin yang cukup besar ini sangat potensial untuk dimanfaatkan sebagai bahan baku pada proses pembuatan lignosulfonat ${ }^{[4,5,6]}$.

Indonesia Pulp \& Paper Industry memprediksikan bahwa dari 32 pabrik pulp dan kertas yang ada di Indonesia menghasilkan 
kapasitas produksi pulp sampai dengan tahun 2005 bisa mencapai 7,6 juta ton ${ }^{[7]}$. Hasil studi di lapangan diketahui bahwa dari produksi 250 ton pulp per hari, diperoleh lindi hitam sebanyak 120 ton per hari atau 43.800 ton per tahun (48\%). Selama ini pabrik pulp dan kertas di Indonesia memanfaatkan limbah lindi hitam sebagai bahan bakar untuk menghasilkan energi selama proses pulping.

Lignin tidak larut dalam air, larutan asam dan larutan hidrokarbon. Lignin dapat disulfonasi dengan sulfit atau bisulfit menghasilkan garam lignosulfonat (LS) (sulfonate lignin).

Proses sulfonasi pada lignin bertujuan untuk mengubah sifat hidrofilitas dari lignin yang tidak larut dalam air dengan memasukkan gugus sulfonat yang lebih polar dari gugus hidroksil, sehingga akan meningkatkan sifat hidrofilitasnya dan menjadikan lignosulfonat larut dalam air. Pemilihan proses sulfonasi tergantung pada banyak faktor, diantaranya yaitu nisbah reaktan, suhu reaksi, waktu atau lama reaksi, $\mathrm{pH}^{[8,9]}$.

Sulfonasi lignin dengan pereaksi natrium sulfit $\left(\mathrm{Na}_{2} \mathrm{SO}_{3}\right)$ ataupun dengan natrium bisulfit $\left(\mathrm{NaHSO}_{3}\right)$ telah dilakukan ${ }^{[10]}$. Natrium bisulfit memiliki keunggulan yaitu produk yang dihasilkan berwarna lebih cerah, mudah diaplikasikan pada skala produk kecil dan dapat digunakan secara batch proses. Reaksi sulfonasi dilakukan $4-8$ jam, pada tekanan atmosfir dengan suhu sekitar $80-100^{\circ} \mathrm{C}$, atau pada tekanan yang lebih tinggi dengan suhu sekitar $120-140^{\circ} \mathrm{C}$, dan proses berlangsung pada $\mathrm{pH} 6,30-7,00$.

Sulfonasi lignin yang berasal dari lindi hitam industri pulp berbahan baku esparto (sejenis rerumputan) juga telah dilakukan ${ }^{[11]}$. Lignin $(\mathrm{pH}$ lignin $=3,00-4,00)$ direaksikan dengan campuran sulfit dan formaldehida dengan rasio mol $(0,6: 0,8)$, suhu sulfonasi $130-160^{\circ} \mathrm{C}$, pada $\mathrm{pH}=7,00-9,00$; selama waktu $3-6$ jam. Konsentrasi sulfit yang digunakan berkisar dari $20-50 \%$ dari berat lignin.

Sulfonasi lignin yang disolasi dari tandan kosong kelapa sawit telah diteliti sebelumnya $^{[12]}$. Kondisi sulfonasi yang dilakukan pada $\mathrm{pH} 5,00$ dan suhu $100^{\circ} \mathrm{C}$.
Sulfonasi dilakukan terhadap $1 \mathrm{~g}$ lignin dengan $37 \%$ natrium bisulfit selama 4 jam.

Dalam penelitian ini dikaji pengaruh nisbah reaktan lignin-natrium bisulfit $\left(\mathrm{NaHSO}_{3}\right)$ dan $\mathrm{pH}$ pada produk natrium lignosulfonat (NaLS).

\section{METODOLOGI}

Proses isolasi lignin mengacu pada metode yang dikembangkan sebelumnya ${ }^{[13]}$ yaitu lindi hitam terlebih dahulu disaring menggunakan kertas saring, kemudian sebanyak $200 \mathrm{~mL}$ filtrat dimasukkan ke dalam erlenmeyer dan ligninnya diendapkan dengan titrasi $\mathrm{H}_{2} \mathrm{SO}_{4}$ $20 \%$.

Sulfonasi lignin modifikasidilakukan dengan cara lignin dicampur dengan $\mathrm{NaHSO}_{3}$ dengan nisbah reaktan $(1,0: 0,4 ; 1,0: 0,5$; dan 1,0:0,6), kemudian disuspensikan dalam $150 \mathrm{~mL}$ air ${ }^{[11,12,14]}$. Nilai $\mathrm{pH}$ campuran adalah 5,00; 6,00; dan 7,00 dengan penambahan $\mathrm{NaOH}$.

Rancangan percobaan yang digunakan dalam penelitian adalah Rancangan Acak Lengkap Faktorial dengan dua faktor perlakuan, yaitu tiga taraf nisbah reaktan lignin- $\mathrm{NaHSO}_{3} \alpha$ yaitu $1,0: 0,4(\alpha 1) ; 1,0: 0,5(\alpha 2)$, dan 1,0:0,6 $(\alpha 3)$, serta tiga taraf $\mathrm{pH} \beta$ yaitu $\mathrm{pH} 5,00(\beta 1)$, $\mathrm{pH} 6,00(\beta 2)$, dan $\mathrm{pH} 7,00(\beta 3)^{[15]}$. Model rancangan percobaan penelitian adalah sebagai berikut:

$$
Y_{i j k}=\alpha_{i}+\beta_{j}+\alpha \beta_{i j}+\varepsilon_{i j k}
$$

- $Y_{i j k}=$ nilai kemurnian nisbah lignin$\mathrm{NaHSO}_{3}$ ke- $i$ dengan $\mathrm{pH}$ awal ke- $j$, dan ulangan ke- $k$

- $\alpha_{i}=$ pengaruh nisbah lignin- $\mathrm{NaHSO}_{3} \mathrm{ke}-i$

- $\beta_{j}=$ pengaruh $\mathrm{pH}$ awal ke-j

- $\alpha \beta_{i j}=$ interaksi antara nisbah reaktan ke- $i$ dengan $\mathrm{pH}$ awal ke-j, dan ulangan ke- $k$

- $\varepsilon_{i j k}=$ pengaruh acak dari nisbah lignin$\mathrm{NaHSO}_{3} \mathrm{ke}-i, \mathrm{pH}$ awal ke-j, dan ulangan ke- $k$

- $\quad \alpha \beta_{i j}=$ interaksi antara nisbah reaktan ke- $i$ dengan $\mathrm{pH}$ ke-j

- $\varepsilon_{i j k}=$ galat dari nisbah reaktan ke-i, $\mathrm{pH}$ awal ke-j dan ulangan ke- $k$ 
Pencirian lignin dan NaLS menggunakan FTIR, dan penentuan kemurnian $\mathrm{NaLS}^{[16]}$.

\section{HASIL DAN PEMBAHASAN}

\section{Kemurnian NaLS}

Hasil analisis keragaman dengan selang kepercayaan $95 \%(\alpha=0,05)$ menunjukkan bahwa nisbah reaktan lignin- $\mathrm{NaHSO}_{3}$ dan $\mathrm{pH}$ awal berbeda nyata terhadap kemurnian yang dihasilkan. Kemurnian yang paling tinggi didapat pada $\mathrm{pH}$ awal 5,00 dan nisbah 1,0:0,6 (Gambar 1). Hal ini dikarenakan reaksi sulfonasi pada $\mathrm{pH}$ awal 5,00 berlangsung lebih sempurna jika dibandingkan $\mathrm{pH}$ awal 6,00 dan 7,00 . Masuknya gugus nukleofilik akan lebih mudah dalam keadaan asam karena mudahnya pembentukan karbokation ${ }^{[17]}$. Reaksi sulfonasi lebih cepat terjadi pada $\mathrm{pH}$ yang rendah ${ }^{[4]}$.

\section{Rendemen NaLS}

Rendemen NaLS adalah persentase perbandingan bobot NaLS yang dihasilkan terhadap bobot lignin awal. Hasil analisis keragaman dengan selang kepercayaan 95\% $(\alpha=0,05)$ menunjukkan bahwa $\mathrm{pH}$ awal dan nisbah reaktan lignin- $\mathrm{NaHSO}_{3}$ berpengaruh nyata terhadap rendemen NaLS yang dihasilkan.

Rendemen NaLS paling besar diperoleh pada pH awal 7 dan nisbah reaktan 1,0:0,6 (Gambar $2 \mathrm{C}$ ), akan tetapi mempunyai kemurnian yang relatif rendah $(68,72 \%)$. Rendemen yang bertambah, diperkirakan karena semakin tinggi $\mathrm{pH}$ maka kelarutan lignin semakin tinggi, sehingga memperbesar luas permukaan lignin yang selanjutnya akan memperbesar peluang terjadinya tumbukan antar molekul.

Demikian juga dengan pengaruh nisbah reaktan $(1,0: 0,6)$. Semakin tinggi konsentrasi $\mathrm{NaHSO}_{3}$ akan meningkatkan persen rendemen sodium lignosulfonat. Hal ini dikarenakan frekuensi terjadinya tumbukan antar pereaksi semakin baik dan sempurna ${ }^{[17]}$. Sementara kemurnian yang relatif rendah pada $\mathrm{pH}$ awal 7,00 dan nisbah reaktan 1,0:0,6, dimungkinkan karena masih tersisanya $\mathrm{NaHSO}_{3}$ sebagai pereaksi pembatas pada produk NaLS.

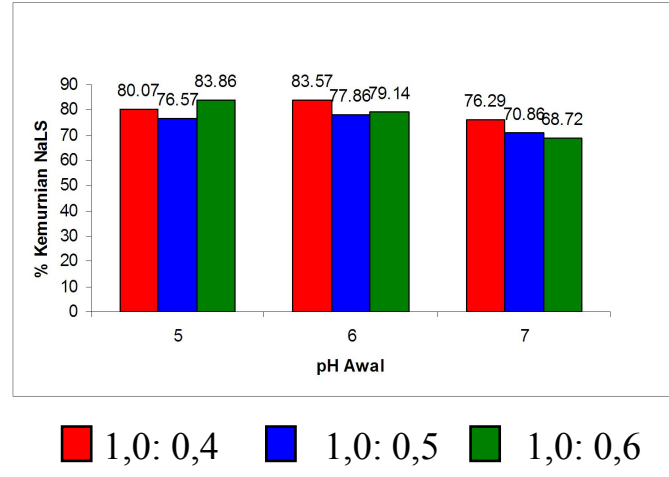

Gambar 1. Kemurnian NaLS pada berbagai nisbah lignin- $\mathrm{NaHSO}_{3}(1,0: 0,4 ; 1,0: 0,5 ;$ dan 1,0:0,6).

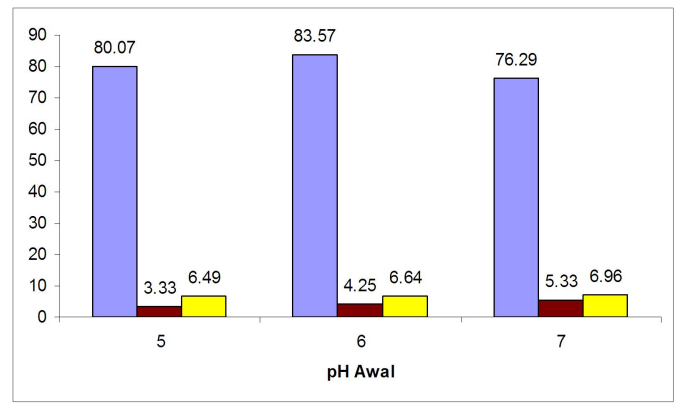

A (nisbah lignin- $\mathrm{NaHSO}_{3} ; 1: 0.4$ )

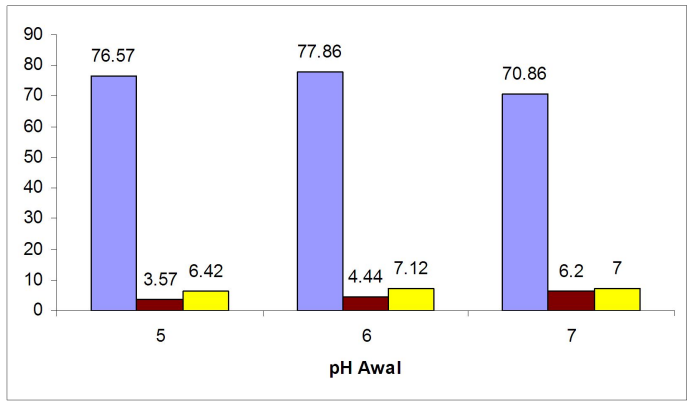

$\mathrm{B}$ (nisbah lignin- $\mathrm{NaHSO}_{3} ; 1: 0.5$ )

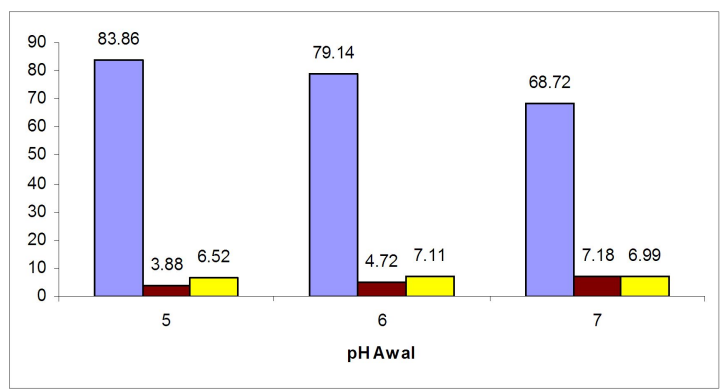

$\mathrm{C}$ (nisbah lignin- $\mathrm{NaHSO}_{3} ; 1: 0.6$ )

$\%$ Kemurnian NaLS $\square$ pH NaLS

Rendemen NaLS

Gambar 2. Persen Kemurnian, Rendemen NaLS pada berbagai nisbah lignin $\mathrm{NaHSO}_{3}(\mathrm{~A}=1,0: 0,4$; $\mathrm{B}=1,0: 0,5 ; \mathrm{C}=1,0: 0,6)$, dan $\mathrm{pH}$ NaLS. 


\section{Nilai pH NaLS}

Pengukuran $\mathrm{pH}$ bertujuan untuk mengetahui derajat keasaman NaLS yang dihasilkan. Hasil analisis keragaman dengan selang kepercayaan 95\% $(\alpha=0,05)$ menunjukkan bahwa nisbah reaktan lignin- $\mathrm{NaHSO}_{3}$ tidak berbeda nyata terhadap pH akhir NaLS. Hasil uji Duncan menunjukkan bahwa $\mathrm{pH}$ awal 6,00 dan 7,00 tidak berbeda nyata terhadap $\mathrm{pH}$ akhir yang dihasilkan. Akan tetapi keduanya berbeda nyata dibandingkan $\mathrm{pH}$ awal 5,00. Terlihat pada Gambar 2 (A, B, C), jika pH awal reaksi sulfonasi 5,00 menghasilkan $\mathrm{pH}$ NaLS berkisar 6,42 - 6,52 lebih rendah dari $\mathrm{pH}$ awal 6,00; 7,00 dengan nilai $\mathrm{pH}$ NaLS berkisar 6,64 7,12 . Hal tersebut disebabkan banyaknya gugus sulfonat yang tersubstitusi pada $\mathrm{pH}$ awal 5,00 . Semakin banyak terbentuknya gugus sulfonat maka keasaman semakin tinggi ${ }^{[18]}$.

Tabel 1 adalah hasil karakterisasi NaLS dibandingkan dengan NaLS (WTL) Wesco Technologies, Ltd. Nilai (\%) gula pereduksi, kadar abu, kadar air, viskositas dan bobot jenis adalah dari nilai NaLS pada kondisi optimum. Berdasarkan kemurnian, rendemen dan
pH NaLS dan karakterisasi NaLS (Tabel 1), maka dipilih kondisi optimum sulfonasi lignin soda pada $\mathrm{pH}$ awal 6,00 dan nisbah lignin$\mathrm{NaHSO}_{3}$ 1,0:0,6. Pada kondisi ini, diperoleh kemurnian $(79,14 \%)$, rendemen $(4,72)$ dan $\mathrm{pH}$ 7,11 .

\section{Pencirian Gugus Fungsi pada Lignin}

Spektrum FTIR lignin soda disajikan pada Gambar 3, dan nilai serapan ditampilkan pada Tabel 2. Pita serapan pada bilangan gelombang $3431,18 \mathrm{~cm}^{-1}$ menunjukkan uluran $\mathrm{O}-\mathrm{H}$, pita serapan pada bilangan gelombang $2926,37 \mathrm{~cm}^{-}$ 1 dan 1459,59 $\mathrm{cm}^{-1}$ menunjukkan uluran $\mathrm{C}-\mathrm{H}$ dari gugus metil. Dua pita serapan pada bilangan gelombang $1616,85 \mathrm{~cm}^{-1}$ dan $1507,61 \mathrm{~cm}^{-1}$ merupakan karakteristik dari cincin aromatik dan pita serapan pada 1116,20 $\mathrm{cm}^{-1}$ menunjukkan uluran eter. Pita serapan pada $840,12 \mathrm{~cm}^{-1}$ menunjukkan vibrasi $\mathrm{C}-\mathrm{H}$ aromatik di luar bidang, sedangkan pita serapan yang khas pada bilangan gelombang $1212,76 \mathrm{~cm}^{-1}$ menunjukkan adanya guaiasil $\left(\right.$ Gambar 4) ${ }^{[19]}$. Guaiasil merupakan salah satu zat penyusun lignin ${ }^{[20]}$.

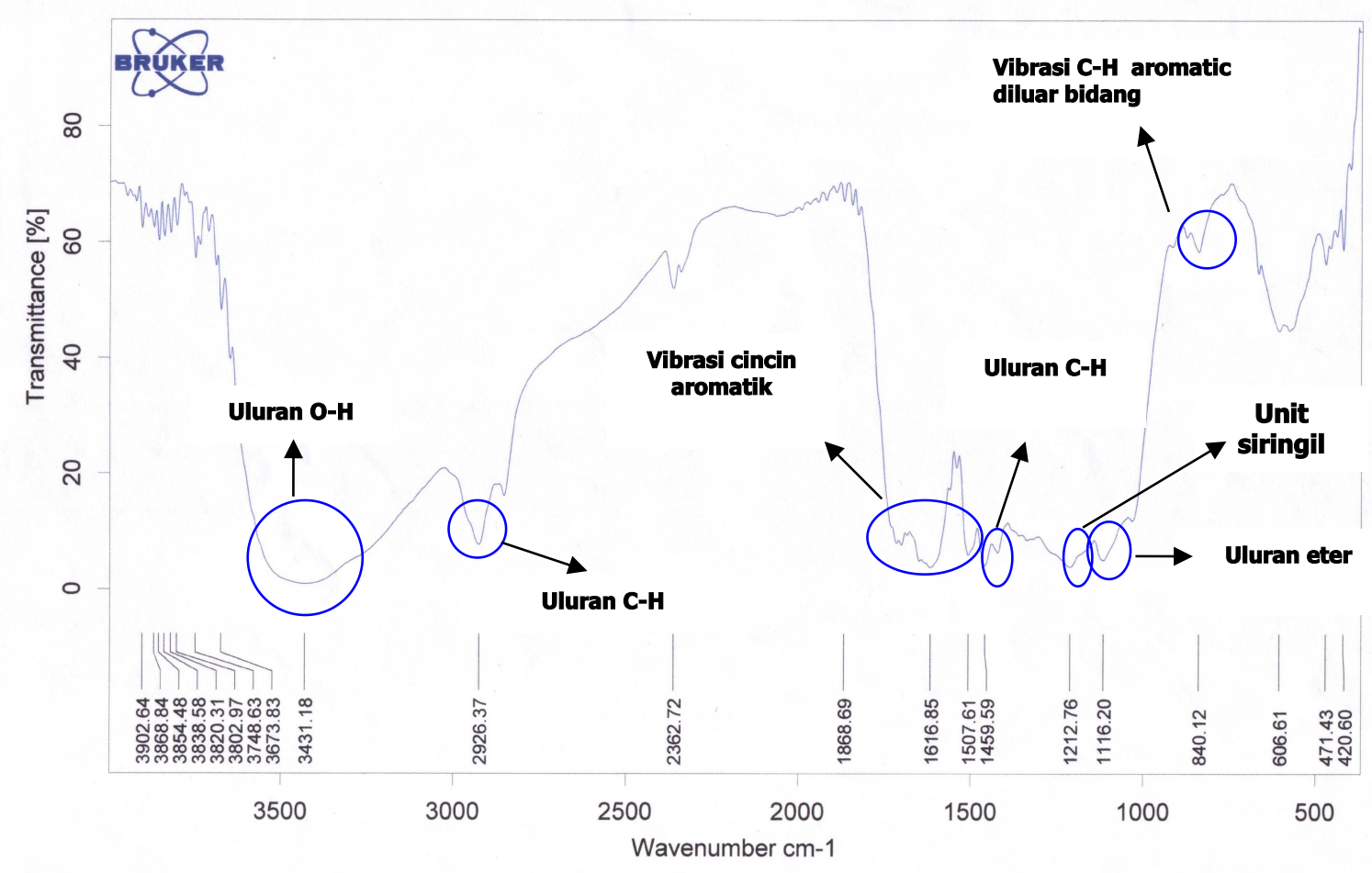

Gambar 3. Spektrum FTIR Lignin 
Tabel 1. Karakteristik Produk NaLS ${ }^{[16]}$

\begin{tabular}{lcc}
\hline \multicolumn{1}{c}{ Parameter } & Nilai & Nilai* \\
\hline NaLS (\%) & $68,72-83,86$ & 80,00 \\
Gula pereduksi (\%) & 4,53 & 7,00 \\
Kadar abu (\%) & 20,26 & 22 \\
Kadar air (\%) & 4,65 & $<6.00$ \\
pH (10\% larutan) & $6,42-7,11$ & 7,00 \\
Viskositas (cps) & 1067 & 1000 \\
Bobot jenis g/cm $\left.{ }^{3}\right)$ & 1,3536 & 1,2764 \\
\hline
\end{tabular}

Tabel 2. Pencirian Gugus Fungsi Lignin

\begin{tabular}{cccc}
\hline $\begin{array}{c}\text { Bilangan } \\
\text { gelombang } \\
\text { lignin hasil isolasi } \\
\left(\mathrm{cm}^{-1}\right)\end{array}$ & $\begin{array}{c}\text { Bilangan gelombang } \\
\left(\mathrm{cm}^{-1}\right)^{[19]}\end{array}$ & $\begin{array}{c}\text { Bilangan gelombang } \\
\left(\mathrm{cm}^{-1}\right)^{[21]}\end{array}$ & Gugus fungsi \\
\hline 3431,18 & 3424 & & Uluran O-H \\
2926,37 & 2930 & 3433 & Uluran C-H gugus metil \\
1616,85 & 1605 & $2940-2930$ & Vibrasi cincin aromatik \\
1507,61 & 1513 & 1610 & Vibrasi cincin aromatik \\
1459,59 & - & 1516 & Uluran C-H gugus metil \\
1212,76 & 1211 & 1464 & Ciri lignin guaiasil \\
1116,20 & - & $1275-1037$ & Uluran eter \\
840 & - & 1117 & Vibrasi C-H aromatik di luar \\
& & $840-830$ & \\
\hline
\end{tabular}

\section{Pencirian Gugus Fungsi pada NaLS}

Spektrum FTIR NaLS, yaitu hasil sulfonasi lignin soda disajikan pada Gambar 4. Nilai serapan ditampilkan pada Tabel 3. Adanya pita serapan yang terjadi pada daerah $1121,31 \mathrm{~cm}^{-1}$ (vibrasi gugus sulfonat), 1038,01 $\mathrm{cm}^{-1}$ (rentangan $\mathrm{S}=\mathrm{O}$ simetri), 994,98 $\mathrm{cm}^{-1}$ (rentangan S-O), serta $619,64 \mathrm{~cm}^{-1}$ (uluran C$\mathrm{S})$ menunjukkan bahwa lignin telah tersulfonasi menjadi natrium lignosulfonat. Serapan ini tidak terlihat pada spektrum lignin.

\section{KESIMPULAN}

Reaksi sulfonasi terhadap lignin oleh $\mathrm{NaHSO}_{3}$ menghasilkan NaLS dengan kemurnian 68,72 $83,86 \%$, pH (10\% larutan) 6,42-7,11, dan rendemen 68,36-144,43\%. Kenaikan pH awal meningkatkan $\mathrm{pH}$ akhir dan rendemen NaLS, tetapi menurunkan kemurniannya. Kenaikan nisbah lignin-NaHSO ${ }_{3}$ meningkatkan rendemen dan menurunkan kemurnian, tetapi tidak berpengaruh pada $\mathrm{pH}$ akhir NaLS. Kondisi optimum reaksi sulfonasi lignin yang dipilih adalah pada $\mathrm{pH}$ awal 6,00 dan nisbah lignin- $\mathrm{NaHSO}_{3}$ 1,0:0,6. Reaksi sulfonasi telah berlangsung. Hal ini dapat dilihat dari adanya pita serapan yang terjadi pada daerah 1121,31 $\mathrm{cm}^{-1}$ (vibrasi gugus sulfonat), 1038,01 $\mathrm{cm}^{-1}$ (rentangan $\mathrm{S}=\mathrm{O}$ simetri), 994,98 $\mathrm{cm}^{-1}$ (rentangan S-O), serta $619,64 \mathrm{~cm}^{-1}$ (uluran CS).

\section{UCAPAN TERIMA KASIH}

Ucapan terima kasih disampaikan kepada Direktorat Jenderal Pendidikan Tinggi Departemen Pendidikan Nasional yang telah membiayai jalannya penelitian ini. 
Tabel 3. Pencirian Gugus Fungsi NaLS

\begin{tabular}{cccc}
\hline $\begin{array}{c}\text { Bilangan } \\
\text { gelombang } \\
\text { NaLS hasil } \\
\text { sintesis } \\
\left(\mathrm{cm}^{-1}\right)\end{array}$ & $\begin{array}{c}\text { Bilangan } \\
\text { gelombang } \\
\left(\mathrm{cm}^{-1}\right)^{[21]}\end{array}$ & $\begin{array}{c}\text { Bilangan } \\
\text { gelombang } \\
\left(\mathrm{cm}^{-1}\right)^{[12]}\end{array}$ & Gugus fungsi \\
\hline 3431,47 & 3433 & 3466 & Uluran O-H \\
2932,79 & $2940-2930$ & $2921-2851$ & Uluran C-H gugus metil \\
1598,93 & 1610 & 1595 & Vibrasi cincin aromatik \\
1511,44 & 1516 & 1508 & Vibrasi cincin aromatik \\
1459,47 & 1464 & 1463 & Uluran C-H gugus metil \\
1121,31 & & $1230-1120$ & Vibrasi gugus sulfonat \\
1038,01 & & 1035 & Rentangan S=O simetri \\
994,98 & & 994,$40 ; 667,48$ & Rentangan S-O \\
835 & $840-830$ & & Vibrasi C-H aromatik di luar \\
& & 528 & bidang \\
619,64 & 620 & & Uluran C-S \\
\hline
\end{tabular}

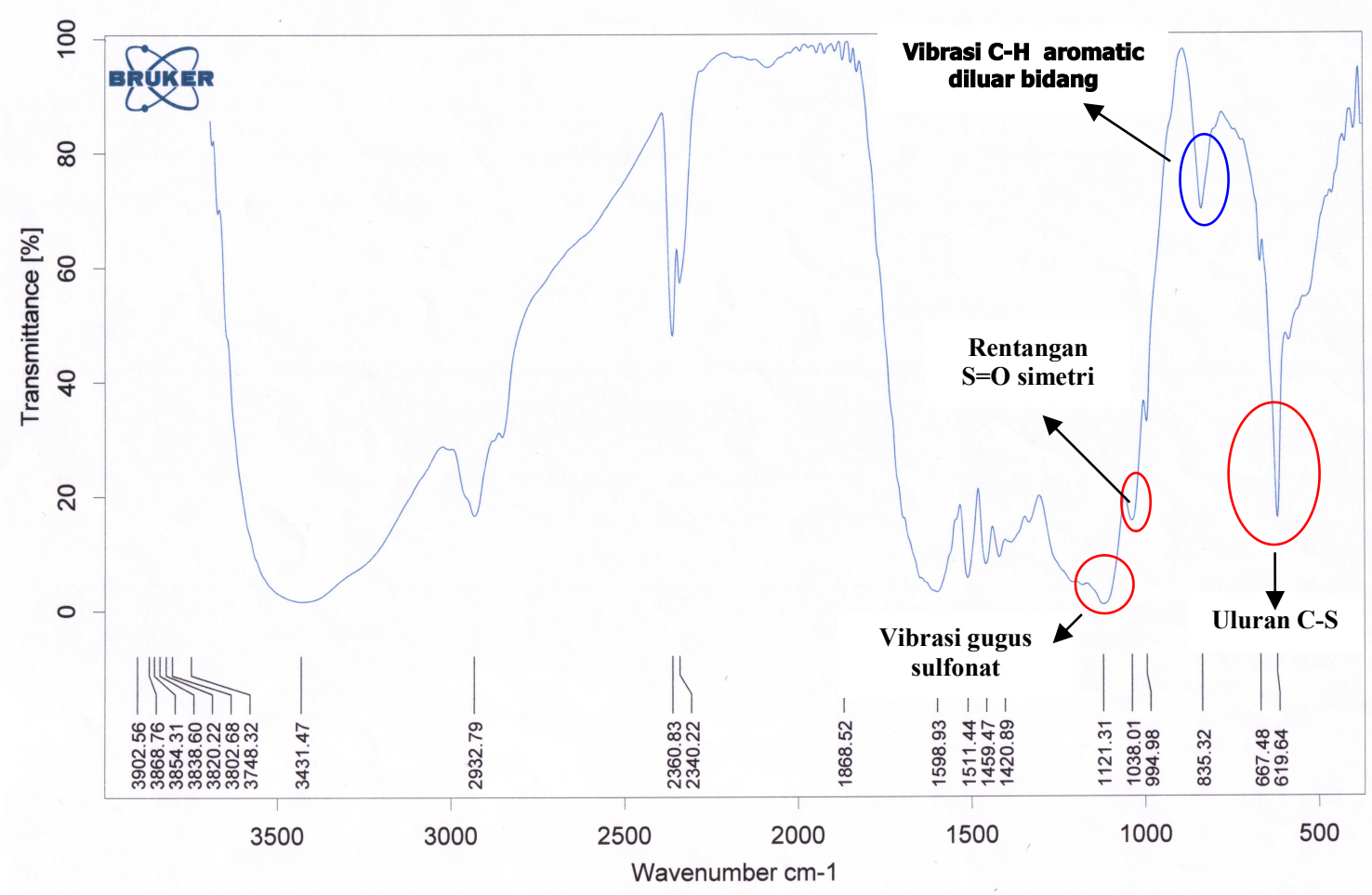

Gambar 4. Spektrum FTIR NaLS

\section{DAFTAR PUSTAKA}

1. Gargulak, J. D., Lebo, S. E., 2000, Commercial use of lignin-based materials. In: Glasser, W.G., Northey, R.A., Schultz, T.P. (Eds.), Lignin: Historical, Biological, and Materials Perspectives. Washington: Oxford University Press, 304-320.

2. Flider, F. J., 2001, Commercial considerations and markets for naturally derived biodegradable surfactants, Inform., 12(12): 1161- 1164. 
3. Mullick, A. K., 1997, Use of lignin-based products in concrete. In: Chandra, S. (Ed.), Waste Materials Used in Concrete, New Jersey: Noyes publications, 352-429.

4. Fengel, D., Wegener, G., 1995, Kayu: Kimia, Ultrastruktur, dan Reaksi-Reaksi, Sastrohamidjojo, H, penerjemah; Yogyakarta: UGM Pr. Terjemahan dari: Wood: Chemistry, Ultrastructure, and Reactions.

5. Sjostrom, E., 1993, Kimia Kayu, DasarDasar dan Penggunaannya. Ed ke-2. Sastrohamidjojo H, penerjemah; Yogyakarta: UGM pr. Terjemahan dari: Wood Chemistry, Fundamentals, and Applications.

6. Brongers, M. P. H., Mierzwa, A. J., 2005, Pulp and Paper, CC Technologies Laboratories, In., Dublin, Ohio, www.corrosioncost.com, 14/9/2005.

7. Indonesia Pulp \& Paper Industry, 2005, Directory 2005 Indonesia Pulp \& Paper Industry Directory.

8. Foster, N. C., 1996, Sulfonation and Sulfation Processes, In: Soap and Detergents: A Theoretical and Practical Review, Spitz L (Ed), Illinois: AOCS Press.

9. Kamoun, A., Châabouni, M., 2000, Chemometrics applied to the optimization of the preparation of hydrotropes for detergents starting from BTX fraction of natural gas, Chemometrics, 616-625.

10. Dilling, P., 1986, penemu; Westvaco Corporation, 20 Mei 1986, Low electrolyte sodium lignosulfonates, US patent 4.590.262.

11. Kamoun, A., Jelidi, A., Chaabouni, M., 2003, Evaluation of the performance of sulfonated esparto grass lignin as a plasticizer-water reducer for cement, Cement and Concrete Research, 33: 9951003.

12. Syahmani, 2000, Isolasi, Sulfonasi dan Asetilasi Lignin dari Tandan Kosong Sawit dan Studi Pengaruhnya Terhadap Proses Pelarutan Urea, Tesis, Program Pascasarjana, Institut Teknologi Bandung.

13. Kim, H., Hill, M. K., Fricke, A. L., 1987, Preparation of Kraft Lignin From Black Liquor, Tappi Journal, 12: 112-115.

14. Dilling, P., et al., Penemu; United State Patent. 9 Jan 1990, Production of Lignosulphonate Additives, 4: 892588.

15. Matjik, A. A., Sumertajaya, I. M., 2002, Perancangan Percobaan dengan Aplikasi SAS dan Minitab Jilid 1. Bogor: IPB Press.

16. [WTL] Wesco Technologies, Ltd, 1995, Typical Properties of Weschem Ammonium Lignosulfonat, Calcium Lignosulfonate, Sodium Lignosulfonate, Zinc Lignosulfonate, San Clemente, CA. 92674-3880, USA., terhubung berkala, http://www.wtl.com/aprops.htm 12/9/2005

17. Sykes, P., 1989, Penuntun Mekanisme Reaksi Kimia Organik. Ed ke-2. Hartono et al., penerjemah; Jakarta: PT Gramedia pr. Terjemahan dari: A Guidebook to Mechanism in Organic Chemistry.

18. Rivai, M., 2004, Kajian Pengaruh Nisbah Reaktan $\mathrm{H}_{2} \mathrm{SO}_{4}$ dan Lama Reaksi Terhadap Kinerja Surfaktan Metil Ester Sulfonat yang Dihasilkan., Tesis, Bogor: Program Pascasarjana, Institut Pertanian Bogor.

19. Santoso, A., 2003, Sintesis dan Pencirian Resin Lignin Resorsinol Formaldehida untuk Perekat Kayu Lamina., Disertasi, Program Pascasarjana, Institut Pertanian Bogor.

20. Lin, S. Y., Dence, C. W., 1992, Methods in Lignin Chemistry, Berlin Heidelberg: Springer-Verlag.

21. Ibrahim, M. N., Chuah, S.B., Wan Rosli, W. D., 2004, Characterization of Lignin Precipitated from Soda Black Liquor of Oil Palm Empty Fruit Bunch Fibers By Various Mineral Acid, AJSTD., 21:57-67. 